\title{
[rec.] Sprachbildung und Sprachkontakt im deutsch-polnischen Kontext, red. Britta Hufeisen, Dagmar Knorr, Peter Rosenberg, Christoph Schroeder, Aldona Sopata, Tomasz Wicherkiewicz, współpr. Barbara Stolarczyk, Peter Lang Verlag, Berlin 2018, F.A.L., t. 62
}

W kwietniu tego roku Zespół Języka Polskiego poza Granicami Kraju Rady Języka Polskiego zapoczątkował cykl seminariów pod tytułem „Dwujęzyczność i wielojęzyczność jako wyzwanie społeczne, kulturowe i edukacyjne”, powołując się na aktualność tej tematyki wynikającą z ,narastających procesów migracyjnych”. W tym kontekście warto przypomnieć publikację poświęconą kształceniu językowemu i polsko-niemieckim kontaktom językowym, która ukazała się stosunkowo niedawno dzięki staraniom polskich i niemieckich lingwistów w renomowanym wydawnictwie Peter Lang. Pomysł na wspólną publikację zrodził się na konferencji Polskiego Towarzystwa Lingwistyki Stosowanej (PTLS) i jego niemieckiego odpowiednika Gesellschaft für Angewandte Linguistik (GAL), która odbyła się w 2015 roku we Frankfurcie nad Odrą. Późniejszy zespół redakcyjny w składzie Britta Hufeisen (Darmstadt), Dagmar Knorr (Hamburg), Peter Rosenberg (Frankfurt nad Odrą), Christoph Schroeder (Poczdam), Aldona Sopata i Tomasz Wicherkiewicz (Poznań) otworzył tam sekcję poświęconą lingwistyce migracyjnej i wielojęzyczności zatytułowaną „Sprachbildung und Sprachkontakt im deutsch-polnischen Kontext” (Kształcenie językowe i kontakt językowy w kontekście niemiecko-polskim). Część referatów z tej sekcji weszła w skład książki, która ukazała się pod tym samym tytułem w 2018 roku jako 62 tom serii Forum Angewandte Linguistik. W pracy nad przygotowaniem publikacji uczestniczyła także Barbara Stolarczyk z Darmstadt.

O ile kwestie związane z historią polsko-niemieckich kontaktów językowych od czasu do czasu zajmują uwagę badaczy, o tyle publikacje poświęcone ich synchronicznemu ujęciu są nadal rzadkie. W omawianej pozycji grupa złożona z renomowanych polskich i niemieckich lingwistów zdecydowała się na ryzykowny krok, zbierając w jednym tomie artykuły poświęcone polsko-niemieckiej dwujęzyczności, nie tylko napisane po niemiecku albo po polsku, lecz także ujmujące dwujęzyczność w rozmaity sposób. Ten krok nazwano programem mającym na celu ,wzbudzenie zainteresowania specyfiką niemiecko-polskiego kontaktu językowego, któremu dotychczas poświęcano (zbyt) mało uwagi” (s. 13, przeł. E.K.). Orientację w całości opracowania ułatwia podział na trzy części stanowiący próbę przyporządkowania zebranych materiałów do trzech zakresów tematycznych: 1) potencjał wynikający z dwujęzyczności i nastawienia wobec niej; 2) studia lingwistyczne poświęcone dwujęzyczności; 3) tereny przygraniczne i wielojęzyczność (przeł. E.K.).

Zgodnie z założeniami lingwistyki kontaktowej ${ }^{1} \mathrm{w}$ tomie zebrano analizy zjawisk, które do niedawna rozpatrywane były w ramach odrębnych dyskursów: socjolingwistycznego,

${ }^{1}$ Nazwa zaproponowana przez Wojciecha Hofmańskiego (Pop(lingwo)kultura - lingwistyka kontaktowa jako kolaż dyscyplin, „Postscriptum Polonistyczne” 1, 2015, nr 15), którą przejęłam jako odpowiednik niemieckiej nazwy dziedziny wiedzy określanej jako Kontaktlinguistik, a której 
psycholingwistycznego albo glottodydaktycznego. W Niemczech, gdzie ukazała się omawiana książka, konieczność poświęcenia im większej dozy uwagi wynika głównie z faktu, że wśród mieszkańców tego kraju z „tłem migracyjnym”2 drugą co do wielkości grupę stanowią osoby, które więzi rodzinne łączą z Polską (s. 7).

I tak pierwsza część tomu poświęcona jest polsko-niemieckiej dwujęzyczności oraz zagadnieniom związanym $\mathrm{z}$ wykorzystaniem tego potencjału na różnych etapach nauczania. Otwiera ją opracowanie Joanny Błaszczak i Marzeny Żygis dotyczące biografii językowych oraz nastawień osób dwujęzycznych do języków, którymi posługują się na co dzień. Autorki przeprowadziły badanie ankietowe, w którym wzięło udział 49 uczniów i uczennic z Berlina, a następnie zadały badanym pytania dotyczące ich dwujęzyczności oraz poczucia przynależności narodowej. Informacje z wypełnionych ankiet oraz transkrypty rozmów dostarczyły informacji na temat wykorzystania obu języków w różnych sferach życia codziennego respondentów, trudności związanych z ich opanowywaniem oraz stosunku do dwujęzyczności. Mimo trudności wynikających z konieczności opanowania obu systemów językowych większość ankietowanych (94\%) była zadowolona z faktu, że posługuje się na co dzień dwoma językami (s. 38), nawet jeżeli stopień ich opanowania nie odpowiadał „konserwatywnej definicji dwujęzyczności, która zakłada perfekcyjne opanowanie obu języków" (s. 41, przeł. E.K.). Joanna Burkhard i Grit Mehlhorn, które przeprowadziły badania na podobnej wiekowo grupie respondentów, zestawiły w swojej ekspertyzie wnioski z analizy wywiadów przeprowadzonych z rodzicami i ich dwujęzycznymi dziećmi na temat stosunku do obu używanych w rodzinie języków z wynikami testów diagnostycznych dotyczących opanowania polskiego słownictwa. Poszukiwały przy tym odpowiedzi na pytanie, jakie czynniki sprzyjają rozwojowi języka pochodzenia. Ich badania potwierdziły sprawdzoną już wcześniej empirycznie tezę, że do takich czynników należy przede wszystkim używanie języka polskiego w rodzinie oraz kontakt z innymi użytkownikami języka pochodzenia (grupa rówieśnicza, krewni spoza rodziny nuklearnej). Wpływ na poziom opanowania słownictwa miały także przyzwyczajenia czytelnicze oraz kontakt z mediami (s. 63). Także Magdalena Wiażewicz przyglądała się młodym dwujęzycznym użytkownikom języka niemieckiego i polskiego z Berlina, dostarczając argumentów na poparcie tezy, że instytucjolnalne kształcenie kompetencji w obu językach służy nie tylko rozwojowi osobistemu dwujęzycznych uczniów, lecz także dostarcza im wiedzy i umiejętności potrzebnych w przyszłym życiu zawodowym. Ponieważ liczba uczniów dwujęzycznych w szkolnictwie zawodowym w Berlinie stale wzrasta, takie kształcenie językowe powinno, zdaniem badaczki, stać się stałym elementem odpowiednich programów nauczania (s. 105).

Jedynie dydaktycznie motywowany artykuł Jana Iluka ${ }^{3}$ i Mariusza Janosza zajmuje się kształceniem językowym dzieci na terenie Polski. Autorzy przedstawili w nim metodę

przedmiotem zainteresowania jest „komunikacja w kontekście realnego współwystępowania różnych systemów językowych" (ibidem, s. 31).

${ }^{2}$ Niem. Migrationshintergrund. Określenie to pozwala na uwzględnienie w statystykach demograficznych nie tylko emigrantów pierwszego pokolenia, lecz także ich dzieci. Za jednostki z tłem migracyjnym uchodzą zarówno osoby, które przyszły na świat jako obywatele innego kraju, jak i te, u których przynajmniej jedno z rodziców ma za sobą doświadczenia migracyjne.

3 Jan Iluk dzielił się wynikami innych swoich badań z czytelnikami „Kształcenia Językowego" w tomach 10 i 11 . 
narracyjną oraz wyniki badania efektywności jej wykorzystania w porównaniu z „tradycyjnymi" metodami nauczania języka niemieckiego stosowanymi w nauczaniu przedszkolnym. Opierając się na tych wynikach, badacze zalecają generalną zmianę postępowania we wczesnym nauczaniu języków obcych. $Z$ tym postulatem wiąże się jednak także konieczność zmiany sposobu kształcenia kadry nauczycielskiej w Polsce (s. 87).

W drugiej części omawianego tomu zebrano trzy artykuły opisujące lingwistyczne spojrzenie na oba języki ukształtowane w sytuacji dwujęzyczności. Na początku tej części umieszczono ciekawą analizę Izabeli Błaszczyk poświęconą użyciu trybu warunkowego w języku polskim, która rzuca światło na hipotezę wieku krytycznego związanego z nabywaniem tej części systemu gramatycznego. Badanie ankietowe przeprowadzone za pośrednictwem internetu na 128 respondentach pozwoliło badaczce na porównanie użycia odpowiednich form gramatycznych u osób monolingwalnych, posługujących się językiem polskim jako odziedziczonym (symultaniczna akwizycja obu języków) oraz bilingwalnych, dla których niemiecki jest językiem drugim (akwizycja sukcesywna). Różnice w używaniu odpowiednich form w tych trzech grupach zdają się wskazywać na to, że do pełnego ukształtowania polskich form trybu przypuszczającego w mowie dziecka dochodzi dopiero między dziewiątym a 11 rokiem życia (s. 136). Jagoda Cieszyńska-Rożek dokonała natomiast analizy biografii językowej dwunastoletniej uczennicy, której zachowania językowe obserwowała przez dziewięć lat. Jej pytanie badawcze dotyczyło przy tym warunków kształtowania się ,zrównoważonego bilingwizmu stymulującego dynamiczny rozwój poznawczy dzieci dwu- i wielojęzycznych" (s. 141). Doszła przy tym do podobnej konkluzji jak Mehlhorn i Burkhardt: „Wysoki poziom opanowania obu języków Julii jest ściśle związany z jej lekturami, pasją czytelniczą i sprawnością pisania” (s. 156). Rafał Suda i Sandra Pappert przyjrzeli się natomiast użyciu niemieckiego rodzajnika określonego na lekcjach w polskiej szkole. Wychodząc od wskaźników determinacji występujących w polszczyźnie spróbowali sprawdzić, czy polscy uczący się języka niemieckiego jako obcego są w stanie skorzystać z transferu pozytywnego przy podejmowaniu decyzji, jakiego rodzajnika użyć w tłumaczeniu z języka polskiego na niemiecki: określonego czy nieokreślonego. Badanie przeprowadzone na 50 uczniach szkół ponadpodstawowych pokazało, że respondenci nie korzystają z implicytnych (nieleksykalnych) wskaźników determinacji w języku polskim, to znaczy — nie wykorzystują potencjału transferu pozytywnego z języka rodzimego, ucząc się języka obcego.

Tematem przewodnim trzeciej i ostatniej części opracowania są tereny przygraniczne i wielojęzyczność. Barbara Alicja Jańczak przedstawiła w swoim artykule wyniki eksperymentu przeprowadzonego w Zgorzelcu i Łęknicy, miastach leżących na styku dwóch kultur i języków. Eksperyment polegał na pytaniu przypadkowych przechodniów o drogę i nagrywaniu tych rozmów. Pytania zadawano najpierw w języku niemieckim, następnie po angielsku, względnie po polsku. Po rozmowie informowano uczestników o celu i sposobie badania oraz proszono o podanie danych socjometrycznych. W ten sposób zgromadzono dane na temat wyboru strategii komunikacyjnych w sytuacjach bilingwalnych u mieszkańców terenów przygranicznych. W żadnej z zarejestrowanych rozmów nie doszło przy tym do zastosowania strategii receptywnej wielojęzyczności ${ }^{4}$. Takiej formie polsko-niemieckiej dwujęzyczności swój artykuł poświęcił socjo- i interlingwista Goro

${ }^{4}$ Więcej na temat znaczenia i historii tego terminu zob. M. Steciąg, Lingua receptiva. Wyzwania wielojęzycznej komunikacji receptywnej w Europie, „Postscriptum Polonistyczne” 26, 2000, nr 2. 
Christoph Kimura, opisując model funkcjonowania komunikacji, w którym każda ze stron produkuje wypowiedzi w swoim języku rodzimym, adekwatnie reagując na sformułowane w innym języku wypowiedzi pozostałych uczestników interakcji (s. 219). Jest to zupełnie inny model komunikacji niż ten, w którym idealnym opanowaniem dwu (i więcej języków) jest przywołana przez Cieszyńską-Rożek „zrównoważona dwujęzyczność”. Rzadkość występowania takiego modelu komunikacji na polsko-niemieckim przygraniczu, zdaniem japońskiego badacza, nie wynika przy tym z natury ludzkiej komunikacji, lecz raczej z braku znajomości języka sąsiada.

Do sytuacji pogranicza nawiązuje także dydaktycznie motywowane opracowanie Tomasza Lisa poświęcone metodzie projektów. Autor opisuje w nim doświadczenia zebrane w nauczaniu języka niemieckiego jako obcego, podając ciekawe przykłady zadań projektowych, które można realizować w oparciu o regionalne treści. Metodą projektową zajęła się także Barbara Stolarczyk. Jej artykuł dotyczy jednak nauczania języka polskiego jako odziedziczonego na uniwersyteckich kursach językowych i opisuje zamysł pracy badawczej poświęconej zbadaniu kompetencji językowych rozwijanych na takich zajęciach. Poza terenem przygranicza zebrane zostały także dane korpusowe przedstawione przez Tirzę Mühlan-Meyer, która w ramach interdyscyplinarnego projektu pod tytułem „Znaki metropolii: wielojęzyczność wizualna na obszarze Zagłębia Ruhry” bada „widoczność, rozmieszczenie, kompozycję oraz postrzeganie i klasyfikowanie pisemnych śladów wielojęzyczności w sferze publicznej" (s. 259, przeł. E.K.). Analiza danych na temat użycia języka polskiego na tym terenie potwierdza często powtarzaną tezę o „niewidoczności” polskich migrantów w Niemczech. Rzadkie występowanie pisemnych śladów polskości w porównaniu $\mathrm{z}$ takimi śladami pozostawionymi $\mathrm{w}$ innych migranckich językach na terenie Zagłębia Ruhry jest dysproporcjonalne do stosunkowo wysokiej liczby mieszkańców tego terenu z polskim them biograficznym.

Lektura artykułów zebranych w omawianym tomie potwierdza przekonanie wyrażone przez Zespół do Spraw Języka Polskiego poza Granicami Kraju, że wielojęzyczność jest wyzwaniem. Wynika to nie tylko z trudności komunikacyjnych, które pojawiają się w wielojęzycznych sytuacjach. Także w obrębie jednego języka widać, jak różnie rozumiane może być na przykład pozornie jasne określenie „dwujęzyczność”. O ile wszystkie badania poświęcone polszczyźnie na terenie Niemiec były prowadzone wśród osób posługujących się językiem polskim jako odziedziczonym ${ }^{5}$, o tyle oba opracowania poświęcone nauczaniu języka niemieckiego w Polsce dotyczą „klasycznej” glottodydaktycznej sytuacji nauczania języka obcego.

Dane dotyczące polsko-niemieckiej dwujęzyczności zebrane za pomocą rozmaitych narzędzi badawczych na terenie Niemiec ukazują ją w nowym świetle, odkrywając

${ }^{5}$ To dosyć nowy termin, który zdaniem Anny Żurek w polskojęzycznej literaturze przedmiotu „wciąż nie jest jeszcze powszechnie używany i jednoznacznie definiowany” (eadem, Strategie komunikacyjne osób dwujęzycznych. Na przykładzie polszczyzny odziedziczonej w Niemczech, Kraków 2018, s. 12). Próbę jego charakterystyki w kontekście glottodydaktycznym podjęły niedawno Ewa Lipińska i Anna Seretny (Język odziedziczony a dwujęzyczność — o konieczności badań komparatywnych, „Acta Universitatis Lodziensis. Kształcenie Polonistyczne Cudzoziemców” 26, 2019, s. 289-292), które doszły do wniosku, że ,ze względu na szeroki zakres użycia terminu JOD [język odziedziczony], posługując się nim, należy zawsze wyraźnie wskazać, do której z wymienionych grup użytkowników ma się odnosić. W glottodydaktyce polonistycznej dotyczy najczęściej języka imigrantów" (ibidem, s. 292). 
dotychczas słabo znane obszary zainteresowań badawczych, które mogą stać się podstawą do podjęcia konkretnych działań politycznych w zakresie kształcenia językowego zarówno na terenach przygranicznych, jak i poza nimi. Dotyczy to w pierwszym rzędzie kształcenia językowego osób posługujących się językami odziedziczonymi, a także kwestii związanych z nauczaniem języka polskiego jako obcego. Szczególnie pożądana z punktu widzenia integracji europejskiej receptywna wielojęzyczność ${ }^{6}$ jako minimalny cel nauczania w kształceniu językowym nie przełożyła się dotychczas na koncepcje kursów i programy nauczania w Niemczech.

W mniejszym stopniu w tomie poruszone zostały sprawy odnoszące się do sytuacji języka niemieckiego w Polsce. Poświęcono im jedynie dwa glottodydaktyczne artykuły. Takie zestawienie treści wyraźnie pokazuje różnice w zainteresowaniach badawczych w obu krajach, a zarazem stanowi pewną próbę ich przezwyciężenia i podjęcia dialogu ponad granicami. Biorąc pod uwagę zmiany demograficzne wynikające $\mathrm{z}$ ruchów migracyjnych w Polsce oraz postępującą integrację europejską, można oczekiwać, że w bliższej lub dalszej przyszłości dojdzie jednak do upodobnienia się dyskursów, nawet jeżeli nie będą one dotyczyły tylko tej jednej konkretnej pary językowej.

Ewa Krauss

ORCID: 0000-0003-1378-9234

Uniwersytet w Jenie

\section{Bibliografia}

Hofmański W., Pop(lingwo)kultura — lingwistyka kontaktowa jako kolaż dyscyplin, „Postscriptum Polonistyczne" 1, 2015, nr 15.

Lipińska E., Seretny A., Język odziedziczony a dwujęzyczność - o konieczności badań komparatywnych, „Acta Universitatis Lodziensis. Kształcenie Polonistyczne Cudzoziemców” 26, 2019.

Meißner F.J., Politische Dimensionen der rezeptiven Mehrsprachigkeits- und Fremdsprachenkonzepte, [w:] Handbuch Mehrsprachigkeits- und Mehrkulturalitätsdidaktik, red. Ch. Fäcke, F.J. Meißner, Narr-Tübingen 2018.

Steciąg M., Lingua receptiva. Wyzwania wielojęzycznej komunikacji receptywnej w Europie, „Postscriptum Polonistyczne" 26, 2000, nr 2.

Żurek A., Strategie komunikacyjne osób dwujęzycznych. Na przykładzie polszczyzny odziedziczonej w Niemczech, Kraków 2018.

${ }^{6}$ Por. F.J. Meißner, Politische Dimensionen der rezeptiven Mehrsprachigkeits- und Fremdsprachenkonzepte, [w:] Handbuch Mehrsprachigkeits- und Mehrkulturalitätsdidaktik, red. Ch. Fäcke, F.J. Meißner, Narr-Tübingen 2018. 